\title{
Đo đổi mới bằng những món đồ mới trong nhà
}

\author{
VÕ VĂN THÀNH
}

September 2, 2009

Tuổi Trẻ Online

https://tuoitre.vn/do-doi-moi-bang-nhung-mon-do-moi-trong-nha-334796.htm 


\title{
Đo đổi mới bằng những món đồ mới trong nhà
}

\author{
TUOI TRE ONLINE
}
* Thưa TS Vương Quân Hoàng, đâu là thành tựu lớn nhất của đổi mới?
- Thành tựu dễ nhận thấy nhất của đổi mới là đời sống của đông đảo nhân dân được cải thiện rõ rệt. Thu nhập bình quân đầu người từ 202 USD vào năm 1986 đã tăng gấp hai lần sau 15 năm, đạt 417 USD vào năm 2001. Với đà tăng trưởng kinh tê cao, nền kinh tế mất thêm sáu năm nữa để nâng mức thu nhập bình quân lên gấp ba lần so với năm 1986.

Cuối năm ngoái, phát biểu trước Quốc hội, Thủ tướng Nguyễn Tấn Dũng nói khả năng năm 2009 thu nhập bình quân đầu người nước ta sẽ đạt khoảng 1.200 USD. Như vậy việc Việt Nam ra khỏi danh sách các nước nghèo trên thế giới có cơ sở để nhìn thấy trước mắt. Tôi biết nhiều gia đình bạn bè tôi trong nhiều năm qua đã đặt mục tiêu mỗi năm sắm sửa một món đồ mới trong nhà, như tivi mới, máy giặt mới, tủ lạnh mới...

Đối với mỗi gia đình, thành tựu đó có thể được đo đếm bằng những đồ vật mới trong nhà, bằng mức tích lũy vốn và tài sản; đối với quốc gia thì thành tựu có thể đo bằng mức độ tăng trưởng kinh tế, bằng thu nhập đầu người năm sau cao hơn năm trước...

Nhưng tôi quan niệm rằng thành tựu lớn nhất mà chúng ta có được trong suốt hành trình đổi mới là sự thay đổi về tư duy kinh tế đối với những người quyết định chính sách cũng như với mỗi người dân. Chính sự thay đổi tư duy đã mang lại của cải và đời sống dễ thở hơn cho tất cả chúng ta.

TS Vương Quân Hoàng sinh năm 1972. Tốt nghiệp TS tại Vương quốc Bỉ (Đại học Tổng hợp Brussels ULB) năm 2004. Hiện TS Vương Quân Hoàng là nhà nghiên cứu kinh tế của bộ môn tài chính thuộc Trung tâm Emile Bernheim ULB, điều phối nghiên cứu tại Việt Nam.

* Sự thay đổi về tư duy kinh tế đó là gì, thưa ông?

- Đó là sự thay đổi về tư duy trong bước chuyển từ nền kinh tế kế hoạch hóa tập trung sang nền kinh tế thị trường. Điều đáng phấn khởi là tư duy kinh tế thị trường ngày càng dứt khoát, mạch lạc hơn. Nhìn vào những năm đầu đổi mới, chúng ta thấy rằng những nguyên tắc tưởng như bất di bất dịch của “đêm trước đổi mới” đã được vượt qua.

Đơn cử quyết định cởi trói cho lưu thông phân phối vào năm 1987, bỏ chính sách hai giá, thực hiện một giá thu mua nông sản, tiếp tục xóa bỏ tình trạng ngăn sông cấm chợ. Còn rất nhiều "những quyết định theo tiếng gọi thị trường" tương tự như vậy, và đằng sau mỗi quyết định chúng ta đều nhìn thấy sự chuyển đổi trong tư duy kinh tế của các nhà làm chính sách.

* Ông vừa đề cập sự thay đổi tư duy kinh tế của cấp làm chính sách, còn với người dân thì sao?

- Theo nhận định của chúng tôi, các nguyên lý kinh tế thị trường chính thức được vận hành từ nửa cuối thập niên 1990 . Tất nhiên là vừa làm vừa sửa hay như 
có người nói là "vừa chạy vừa xếp hàng”. Kết quả là sau nhiều năm nhất quán chính sách đổi mới, nền kinh tế nước ta xuất hiện thêm nhiều loại thị trường mới rất quan trọng. Nghĩa là có thêm nhiều người tham gia mua bán. Có thêm nhiều loại hàng hóa, dịch vụ có thể và có nhu cầu được trao đổi. Tinh thần kinh doanh là một trong những động lực quan trọng dẫn đến sự phồn vinh của xã hội.

Trong những ngày tháng đặc biệt khó khăn về kinh tế từ đầu năm 2009 đến nay, đã có gần 48.000 doanh nghiệp đăng ký thành lập mới. Chúng ta không quá lạc quan, vì nền kinh tế nói chung vẫn còn nhiều vấn đề cần mổ xẻ, nhưng rõ ràng đó là một con số biết nói về tinh thần kinh doanh của người Việt hiện nay.

* Một số nhà kinh tế cho rằng có lẽ những cải cách của quá trình đổi mới đã cơ bản phát huy hết khả năng nội tại của mình. Muốn có bước đột phá mới phải có cuộc đổi mới tiếp theo. Ông nghĩ sao?

- Nếu như tinh thần "nhìn thẳng vào sự thật, đánh giá đúng sự thật, nói rõ sự thật” từng là cảm hứng chủ đạo của đổi mới năm 1986, thì tinh thần này chắc hẳn vẫn cần cho hôm nay và mai sau. Bên cạnh những thành tựu của đồi mới, chúng ta cũng dễ dàng chỉ ra những điểm yếu của nền kinh tế Việt Nam hiện nay. Ngay trong những tháng cuối năm 2009, nguy cơ tái lạm phát đang rình rập... Đặt trong bối cảnh so sánh với các nền kinh tế phát triển trong khu vực và trên thế giới, mới thấy rằng thành tựu về kinh tế của chúng ta dẫu to lớn nhưng hãy còn khiêm tốn.

Quá trình toàn cầu hóa đang được đẩy nhanh sẽ đặt ra nhiều thách thức về tư duy và phương pháp kinh tế. Đó là cuộc đua khốc liệt mà trên đường đua các tay đua buộc phải hoàn thiện mình để vươn lên, và chí ít là không được tụt lùi quá xa so với đối thủ (hay đối tác). Việc này xứng đáng là mối quan tâm chung của xã hội, cần sự góp tay của từng người dân chứ không riêng ai.

* Thưa ông, đâu là những cột mốc đánh dấu các thành tựu kinh tế của nước ta trong hơn 20 năm qua?

- Kể ra thì rất nhiều, nhưng tôi xin đơn cử một vài dấu mốc sau. Thứ nhất là việc thực hiện chính sách kinh tế nhiều thành phần. Thứ hai là đổi mới hệ thống tài chính, ngân hàng, thương mại. Việc cải cách hệ thống ngân hàng, chuẩn bị cho sự ra đời của hệ thống ngân hàng hai cấp - nền móng trọng yếu đầu tiên cho hệ thống tài chính vận hành theo cơ chế thị trường - được bắt đầu từ giữa năm 1986 với việc ông Võ Văn Kiệt (khi đó là phó chủ tịch Hội đồng Bộ trưởng) - tập hợp các chuyên gia để tìm cách cải tiến hệ thống ngân hàng. Thứ ba là đổi mới chính sách phát triển nông nghiệp.

Thứ tư là chủ động hội nhập khu vực và quốc tế. Thứ năm là hình thành hệ thống luật pháp phù hợp với cơ chế thị trường như: Bộ luật dân sự, Luật đầu tư, Luật thương mại, Luật ngân hàng và các tổ chức tín dụng, Luật doanh nghiệp, các luật về thuế...

Võ Văn Thành (Tuổi Trẻ; 02/09/2009 08:51 GMT 


\section{Tài liệu tham khảo:}

[1] Phạm Minh Chính, Vương Quân Hoàng. (2008). Bối cảnh tài chính Việt Nam 1997-1998 và 2007-2008: khoảng cách và biến đổi. Nghiên cúu Kinh tế, 48(7), 3-24.

[2] Phạm Minh Chính, Vương Quân Hoàng. (2009). Kinh tế Việt Nam: Thăng trầm và đột phá. Nxb Chính trị Quốc gia, Hà Nội. 